\title{
Pengaruh Single Tuned Filter Terhadap Frekuensi Harmonik ke-3 Pada Beban Rumah Tangga 2200 VA
}

\author{
Randy $^{1}$, Endah Setyaningsih ${ }^{1}$, Tjandra Susila ${ }^{2}$
}

\begin{abstract}
Home load 2200 VA is one of the non-linear loads that contains harmonic distorted waves. Harmonics is the integer multiplication periodically to the fundamental frequency. The resulting harmonics can aggravate the quality of the non-linear load, one consequence is to shorten the non-linear load life due to overheating. The resulting harmonics can be calculated with Total Harmonic Distortion. This research discusses the influence of Single Tuned Filter on 3rd harmonic frequency at 2200 VA Home load to reduce 3 rd harmonic frequency value. Tests conducted in this research is testing the positive effect of decreasing the $3 r d$ harmonic frequency on the values of $T H D_{V}$ and $T H D_{I}$ to the value of power factor. Based on the results of the tests that have been done, decreasing the $3 r d$ harmonic frequency on the values of $T H D_{V}$ and $T H D_{I}$ have a positive influence on the value of power factor. Values $T H D_{V}$ and $T H D_{I}$ before filter fitted have significant differences than values $T H D_{V}$ and $T H D_{I}$ after fitted filter. The power factor value before filtering has a significant difference over the power factor value after it has been filtered.
\end{abstract}

KEYWORDS: Home load 2200 VA, Harmonic, THD, 3rd harmonic frequency, power factor, Single Tuned Filter.

\begin{abstract}
ABSTRAK: Beban Rumah Tangga 2200 VA adalah salah satu beban non-linier yang menggambarkan gelombang yang terdistorsi yang mengandung harmonik. Harmonik adalah perkalian integer secara periodik terhadap frekuensi fundamental. Harmonik-harmonik yang timbul tersebut dapat memperburuk kualitas dari Beban non-linier tersebut, salah satu akibatnya adalah memperpendek umur beban nonlinier tersebut karena overheating yang terlalu berlebihan. Harmonik-harmonik yang timbul tersebut dapat dihitung dengan Total Harmonic Distortion. Penelitian ini membahas mengenai pengaruh Single Tuned Filter terhadap Frekuensi harmonik ke-3 pada Beban Rumah Tangga 2200 VA untuk mereduksi nilai frekuensi harmonik ke-3. Pengujian yang dilakukan dalam penelitian ini adalah pengujian pengaruh positif penurunan frekuensi harmonik ke-3 pada nilai $\mathrm{THD}_{\mathrm{V}}$ dan $\mathrm{THD}_{\mathrm{I}}$ terhadap nilai faktor daya. Berdasarkan hasil pengujian yang telah dilakukan penurunan nilai frekuensi harmonik ke-3 pada nilai $\mathrm{THD}_{\mathrm{V}}$ dan $\mathrm{THD}_{\mathrm{I}}$ memiliki pengaruh positif terhadap nilai faktor daya. Nilai $\mathrm{THD}_{\mathrm{V}}$ dan $\mathrm{THD}_{\mathrm{I}}$ sebelum dipasangi filter memiliki perbedaan yang signifikan daripada Nilai $\mathrm{THD}_{\mathrm{V}}$ dan $\mathrm{THD}_{\mathrm{I}}$ sesudah dipasangi filter. Nilai faktor daya sebelum dipasangi filter memiliki perbedaan yang signifikan daripada nilai faktor daya sesudah dipasangi filter.
\end{abstract}

KATA KUNCI: Beban Rumah Tangga 2200 VA, harmonik, THD, frekuensi harmonik ke-3, faktor daya, Single Tuned Filter.data

\section{PENDAHULUAN}

$\mathrm{E}^{\mathrm{n}}$ nergi listrik merupakan sesuatu yang dapat dikatakan menjadi kebutuhan sehari-hari dalam melakukan aktivitas. Energi listrik membuat segala sesuatu lebih efisien dalam menjalani aktivitas, contohnya saat melakukan sebuah kegiatan di malam hari. Dahulu lilin, petromak, atau penerangan lainnya yang tidak menggunakan energi listrik digunakan untuk penerangan saat beraktivitas pada malam hari tetapi sekarang setelah energi listrik ditemukan ketika pada waktu malam hari, lampu menjadi alat penerangan untuk membantu melakukan aktivitas. Tanpa energi listrik hampir tidak mungkin aktivitas dapat dilakukan dengan sempurna. Seiring dengan berjalannya waktu kebutuhan energi listrik semakin hari semakin meningkat. Pada jaman sekarang ini kemajuan teknologi menuntut energi listrik yang lebih besar daripada sebelumnya.

Ada dua faktor yang menentukan baik buruknya performansi energi listrik, yaitu: kuantitas dan kualitas listrik. Kuantitas daya listrik merupakan berapa besar nilai daya listrik yang dihasilkan oleh pembangkit listrik untuk dipakai. Kualitas listrik dapat dibedakan menjadi tiga elemen, yaitu: arus, tegangan, dan frekuensi listrik. Tiga elemen ini merupakan hal yang sangat berpengaruh terhadap kualitas dari listrik tersebut. Daya listrik yang akan dihantarkan akan menjadi buruk bila terjadi penyimpangan terhadap arus, tegangan dan frekuensi listrik ini. Sebagai contoh penyimpangan terhadap arus, tegangan dan frekuensi adalah nilainya yang berubah-ubah seperti tegangan yang diterima pada rumah tangga seharusnya 220 Volt tetapi yang diterima pada rumahtangga kurang dari 220 Volt tidak pernah diterima 220 Volt secara stabil. Buruknya kualitas daya listrik ini akan menyebabkan pemakaian listrik yang tidak maksimal.

Masalah yang sering dihadapi oleh energi listrik adalah terjadinya distorsi harmonik. Distorsi harmonik adalah gangguan yang terjadi pada sistem distribusi tenaga listrik akibat terjadinya distorsi gelombang arus dan tegangan[1]. Distorsi harmonik ini juga memiliki efek buruk bagi PLN, yaitu menyebabkan kondisi pembebanan yang seharusnya masih bisa dilayani sistem menjadi overload karena meningkatnya arus harmonisa. Gelombang harmonik ini kemudian bersuperposisi dengan gelombang dasarnya sehingga terbentuk gelombang yang terdistorsi. Gelombang yang seharusnya sinusoidal murni akibat terjadinya distorsi akan berubah menjadi gelombang sinusoidal yang tidak murni atau bahkan menjadi gelombang non-sinusoidal. Distorsi harmonik ini terjadi dikarenakan beban non-linier. Beban non-linier adalah bentuk gelombang keluarannya tidak sebanding dengan tegangan dalam setiap setengah siklus sehingga bentuk gelombang arus maupun tegangan keluarannya tidak sama dengan gelombang masukkannya[1]. Beban non-linier ini adalah peralatan semikonduktor, peralatan elektronik, dan komponen-komponen lainnya.

\footnotetext{
${ }^{1}$ Program Studi Teknik Elektro, Fakultas Teknik, Universitas Tarumanagara

${ }^{2}$ Program Studi Teknik Elektro, Universitas Trisakti
} 
Total Harmonic Distortion (THD) dapat menghitung harmonik-harmonik yang timbul. Total Harmonic Distortion ini diukur sebagai presentase, yang dimana semakin besar nilai THD-nya semakin buruk kualitas dari suatu beban non-linier, dan apabila nilai THD-nya semakin kecil maka semakin baik kualitas dari beban tersebut. Nilai THD juga mempengaruhi nilai faktor daya. Nilai faktor daya merupakan sebuah nilai yang dapat menentukan baik buruknya suatu daya listrik. Nilai THD tinggi akan menghasilkan nilai faktor daya rendah dan nilai THD rendah akan menghasilkan nilai faktor daya tinggi. Dengan mereduksi nilai THD berdasarkan arus (THDi) dan tegangan (THDv) akan menghasilkan nilai faktor daya yang tinggi. Semakin tinggi nilai faktor daya maka semakin baik daya listrik tersebut.

Salah satu cara untuk mereduksi nilai THD adalah merancang sebuah filter untuk hanya melewatkan frekuensi fundamental, sehingga frekuensi harmonik yang tidak diinginkan tidak dapat mengganggu performansi dari beban non-linier tersebut. Survei pertama dilakukan pada tanggal 28 Oktober 2016 dari jurnal yang berjudul "Perancangan Low Pass RC Filter untuk Mereduksi Harmonik pada Lampu Hemat Energi (LHE) 20W" [9]. Survei ini dilakukan untuk mengetahui bagaimana hasil kerja dari filter low pass RC filter dalam mereduksi harmonik pada lampu hemat energi, filter ini mampu mereduksi harmonik dan menaikkan nilai faktor daya. Survei kedua dilakukan pada tanggal 2 september 2016 dari jurnal yang berjudul "Analisis Unjuk Kerja Harmonik di Instalasi Listrik Industri dan Upaya Penanggulangannya" [8]. Survei kedua ini dilakukan untuk melihat bagaimana Filter Penala Tunggal/Single Tuned Filter bekerja dalam mereduksi harmonik di instalasi listrik industri. Hasil dari survei kedua ini membuktikan bahwa Filter Penala Tunggal/Single Tuned Filter mampu mereduksi harmonik serta menaikkan nilai faktor daya. Penelitian ini akan merancang sebuah filter pasif yang dapat digunakan untuk mereduksi harmonik dan menaikkan nilai faktor daya. Filter pasif yang akan dirancang adalah jenis single tuned filter, filter ini menggunakan dua komponen sederhana yaitu kapasitor dan induktor. Perbedaan pertama Single Tuned Filter dengan Low Pass RC Filter ini adalah didalam performansinya, Single Tuned Filter mereduksi harmonik dengan cara mengambil satu frekuensi untuk direduksi sedangkan Low Pass RC Filter mereduksi harmonik dengan cara memotong frekuensi sesuai dengan frekuensi yang ditentukan. Perbedaan kedua Single Tuned Filter dengan Low Pass RC Filter adalah Single Tuned Filter tidak menggunakan frekuensi resonansi sedangkan Low Pass RC Filter menggunakan frekuensi resonansi. Perbedaan ketiga adalah Single Tuned Filter dipasang seri dengan beban sedangkan Low Pass RC Filter dipasang paralel dengan beban. Penelitian ini akan merancang Single Tuned Filter untuk mereduksi harmonik dan menaikkan nilai faktor daya.

\section{DISTORSI HARMONIK}

\section{DESKRIPSI KONSEP}

Secara umum sistem listrik terbagi atas 2 jenis, yaitu: sistem DC (Direct current) dan sistem AC (Alternating Current). Sistem DC (Direct Current) adalah sistem listrik yang tidak memiliki perubahan polaritas terhadap waktu atau dapat diartikan bahwa arusnya konsisten terhadap suatu waktu. Sistem AC (Alternating Current) adalah sistem listrik yang memiliki perubahan polaritas terhadap waktu dengan frekuensi yang tertentu. Indonesia menggunakan sistem kelistrikan AC dengan frekuensi $50 \mathrm{~Hz}$. Gambar 1. menunjukkan gelombang Alternating Current.

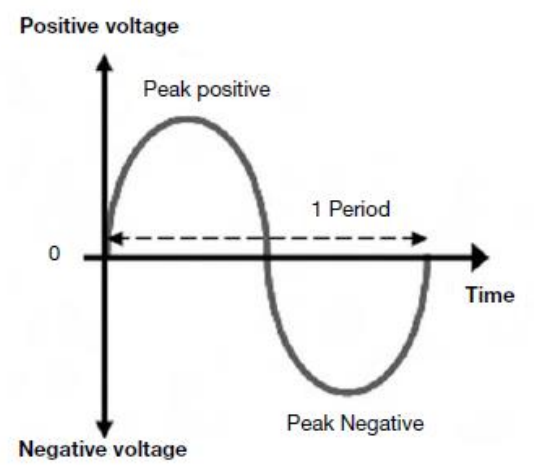

Gambar 1. Gelombang Alternating Current [2]

Berdasarkan Gambar 2.1. dapat dilihat bahwa gelombang AC merupakan bentuk dari gelombang sinusoidal murni, tetapi pada kenyataannya gelombang sinusoidal murni ini tidaklah sempurna melainkan memiliki cacat atau distorsi. Distorsi yang terjadi pada gelombang ini merupakan salah satu bentuk dari distorsi harmonik.

Gelombang Harmonik merupakan gejala terbentuknya gelombang sinusoidal baru yang memiliki frekuensi dari perkalian bilangan bulat dengan frekuensi aslinya. Gelombang yang terdistorsi merupakan hasil dari superposisi dari gelombang dasar dengan gelombang frekuensi harmonik. Gelombang yang terdistorsi akan menghasilkan gelombang tidak lagi sinusoidal murni, fenomena ini disebut dengan distorsi harmonik. Gambar 2. menunjukkan gelombang yang telah terdistorsi. 


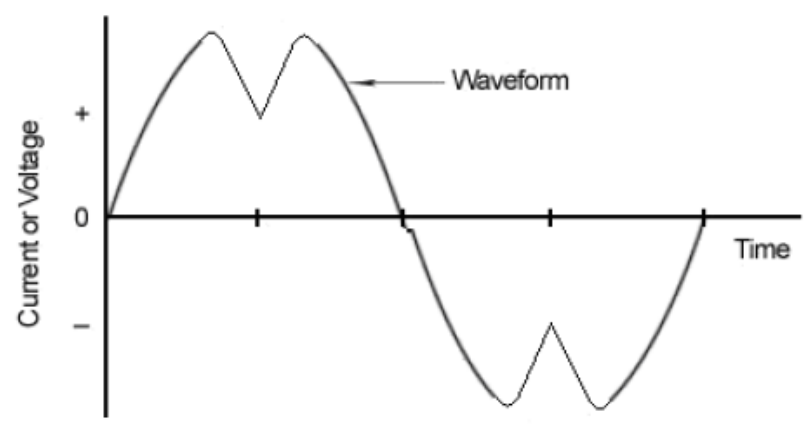

- Gambar 2. Gelombang yang telah terdistorsi [1]

Jika frekuensi fundamental adalah $50 \mathrm{~Hz}$ maka frekuensi harmonik kedua adalah $100 \mathrm{~Hz}$, frekuensi harmonik ketiga adalah $150 \mathrm{~Hz}$, frekuensi harmonik keempat adalah $200 \mathrm{~Hz}$, dan seterusnya. Gambar 3 . menunjukkan perbedaan frekuensi fundamental dan frekuensi harmoniknya.

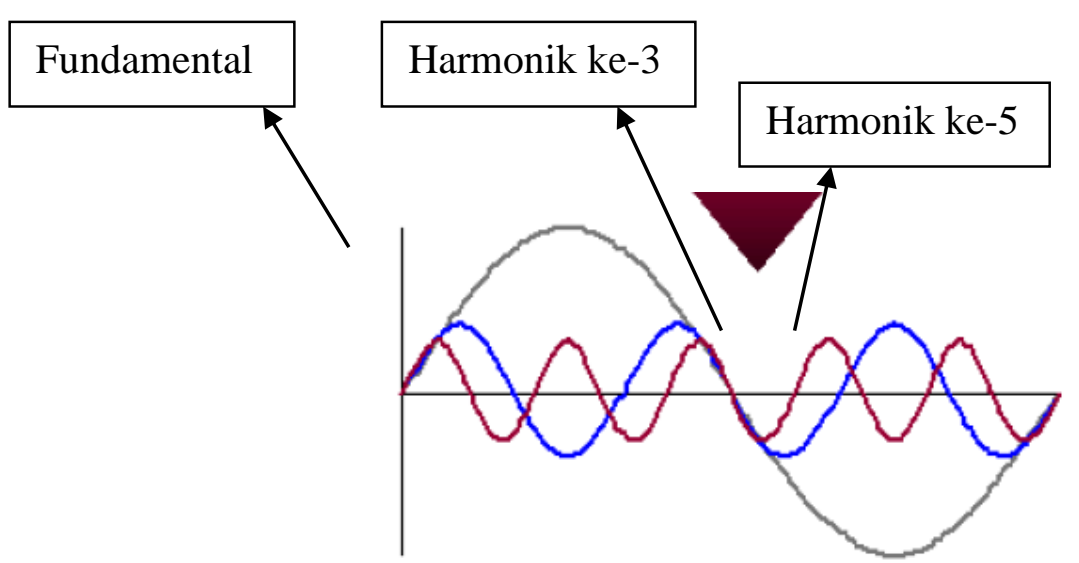

Gambar 3. Gelombang frekuensi fundamental dan frekuensi harmonik [3]

\section{ORDE HARMONIK}

Orde harmonik adalah bilangan bulat yang dijadikan faktor pengali frekuensi lama untuk dijadikan frekuensi baru. Nilai dari orde harmonik merupakan perbandingan antara frekuensi harmonik dengan frekuensi fundamentalnya.

Rumus:

$N=\frac{f n}{F}$

Keterangan:

$\mathrm{n}=$ orde harmonik

$\mathrm{fn}=$ frekuensi harmonik ke-n $(\mathrm{Hz})$

$\mathrm{F}=$ frekuensi dasar $(\mathrm{Hz})$

Gelombang dengan frekuensi dasar tidak dianggap sebagai frekuensi harmonik melainkan adalah frekuensi fundamentalnya. Frekuensi yang dianggap frekuensi harmonik adalah frekuensi orde ke-2 sampai orde ke-n.

\section{INDIVIDUAL HARMONIC DISTORTION (IHD)}

Individual Harmonic Distortion adalah perbandingan nilai tegangan/arus harmonik terhadap nilai tegangan/arus fundamentalnya atau dapat disebut juga sebagai rasio tegangan/arus antara nilai RMS harmonik dengan nilai RMS fundamentalnya.

Rumus:

$\operatorname{IHD}_{\mathrm{n}}=\sqrt{\frac{\mathrm{M}_{\mathrm{n}}{ }^{2}}{\mathrm{M}_{1}^{2}}}$.

Keterangan:

$\mathrm{IHD}_{\mathrm{n}}=$ Individual Harmonic Distortion orde harmonik ke-n $(\mathrm{n}=2,3$, dst.) 
$\mathrm{M}_{\mathrm{n}}=$ nilai rms arus atau tegangan harmonik ke-n (ampere atau volt)

$\mathrm{M}_{1}=$ nilai rms arus atau tegangan fundamental (ampere atau volt)

\section{TOTAL HARMONIC DISTORTION (THD)}

Total Harmonic Distortion adalah presentase total nilai tegangan / arus harmonik terhadap nilai tegangan/arus fundamentalnya. Nilai THD merupakan batasan tegangan atau arus yang dapat ditoleransi dalam sistem tenaga listrik. Nilai THD berdasarkan tegangan biasa dikenal dengan THDv. Nilai THD berdasarkan arus biasa dikenal dengan THDi.

Rumus:

$\mathrm{THD}=\frac{\sqrt{\sum_{n=2}^{n=\infty} M_{n}^{2}}}{M_{1}}$

Keterangan :

THD = Total Harmonic Distortion (\%)

$\mathrm{M}_{\mathrm{n}}=$ nilai rms arus atau tegangan harmonik ke-n (ampere atau volt)

$\mathrm{M}_{1}=$ nilai rms arus atau tegangan fundamental (ampere atau volt)

\section{TOTAL DEMAND DISTORTION}

Total Demand Distortion adalah perbandingan total nilai arus harmonik terhadap nilai arus beban maksimumnya. Total Demand Distortion dapat dihitung dengan rumus dibawah ini.

Rumus:

$\mathrm{TDD}=\frac{\sqrt{\sum_{\mathrm{n}=2}^{\mathrm{n} \max } \mathrm{I}_{\mathrm{n}}^{2}}}{\mathrm{I}_{\mathrm{L}}}$

Keterangan:

$\mathrm{I}_{\mathrm{n}}=$ Arus harmonik ke-n (ampere)

$\mathrm{I}_{\mathrm{L}}=$ Arus beban maksimum (ampere)

\section{POWER FACTOR}

Power factor atau faktor daya adalah perbandingan antara daya aktif/nyata (P/Watt) dengan daya tampak/semu (S/VA). Daya aktif/nyata adalah hasil dari tegangan root-mean-square (rms) dan arus root-meansquare (rms). Daya semu merupakan hasil dari perkalian antara arus dan tegangan dari listrik pada suatu beban. Faktor daya memiliki rentang $0-1$. Bila faktor daya sama dengan 1 berarti tegangan dan arus memiliki fasa dan gelombang yang tidak terdistorsi.

Rumus:

$\mathrm{PF}=\frac{\mathrm{P}}{\mathrm{S}}$.

Keterangan:

$\mathrm{PF}=$ Power Factor

$\mathrm{P}=$ Daya Nyata (watt)

$\mathrm{S}=$ Daya Semu (volt ampere/VA)

\section{NILAI ROOT - MEAN - SQUARE (RMS)}

Nilai root-mean-square/RMS adalah nilai akar dari nilai suatu fungsi yang dikuadratkan. Nilai RMS harmonik didapatkan oleh gelombang tegangan/arus yang telah terdistorsi. Nilai RMS dapat dihitung dengan rumus di bawah ini.

Rumus:

$r m s=\sqrt{\sum_{n=1}^{n \max } M_{n}^{2}}=M_{1} \sqrt{1+T H D^{2}}$.

Keterangan:

$M_{n}=$ nilai rms dari arus / tegangan ke-n (VA)

\section{STANDAR HARMONIK}

Standar yang diciptakan oleh Institute of Electrical and Electronics Engineer (IEEE) tentang batasan harmonik adalah standar IEEE 519-1992. Standar ini memiliki dua batasan yaitu batas distorsi arus dan batasan distorsi tegangan. Tabel 1. menunjukkan batas distorsi untuk arus dan Tabel 2. menunjukkan batas distorsi untuk tegangan. 
Tabel 1. Batas Distorsi untuk Arus dari IEEE 519-1992 [4]

\begin{tabular}{|c|c|c|c|c|c|c|}
\hline \multicolumn{7}{|c|}{$\begin{array}{l}\text { Maximum Harmonic Current Distortion } \\
\text { in Percent of } I_{\mathrm{L}}\end{array}$} \\
\hline \multicolumn{7}{|c|}{ Individual Harmonic Order (Odd Harmonics) } \\
\hline$I_{\mathrm{sc}} / I_{\mathrm{L}}$ & $<11$ & $11 \leq h<17$ & $17 \leq h<23$ & $23 \leq h<35$ & $35 \leq h$ & $\mathrm{TDD}$ \\
\hline$<20^{*}$ & 4.0 & 2.0 & 1.5 & 0.6 & 0.3 & 5.0 \\
\hline $20<50$ & 7.0 & 3.5 & 2.5 & 1.0 & 0.5 & 8.0 \\
\hline $50<100$ & 10.0 & 4.5 & 4.0 & 1.5 & 0.7 & 12.0 \\
\hline $100<1000$ & 12.0 & 5.5 & 5.0 & 2.0 & 1.0 & 15.0 \\
\hline$>1000$ & 15.0 & 7.0 & 6.0 & 2.5 & 1.4 & 20.0 \\
\hline \multicolumn{7}{|c|}{ Even harmonics are limited to $25 \%$ of the odd harmonic limits above. } \\
\hline \multicolumn{7}{|c|}{$\begin{array}{l}\text { Current distortions that result in a dc offset, e.g., half-wave converters, are not } \\
\text { allowed. }\end{array}$} \\
\hline \multicolumn{7}{|c|}{$\begin{array}{l}\text { *All power generation equipment is limited to these values of current distortion, } \\
\text { regardless of actual } I_{\mathrm{sc}} / I_{\mathrm{L}} \text {. }\end{array}$} \\
\hline \multicolumn{7}{|l|}{ where } \\
\hline \multicolumn{7}{|c|}{$\begin{aligned} I_{\mathrm{sc}}= & \text { maximum short-circuit current at PCC. } \\
I_{\mathrm{L}}= & \text { maximum demand load current (fundamental frequency component) at } \\
& \text { PCC. }\end{aligned}$} \\
\hline
\end{tabular}

Tabel 2. Batas Distorsi untuk Tegangan dari IEEE 519-1992 [4]

\begin{tabular}{ccc}
\hline Bus Voltage at PCC & $\begin{array}{c}\text { Individual Voltage } \\
\text { Distortion }(\%)\end{array}$ & $\begin{array}{c}\text { Total Voltage } \\
\text { Distortion THD (\%) }\end{array}$ \\
\hline $69 \mathrm{kV}$ and below & 3.0 & 5.0 \\
$69.001 \mathrm{kV}$ through $161 \mathrm{kV}$ & 1.5 & 2.5 \\
$161.001 \mathrm{kV}$ and above & 1.0 & 1.5 \\
\hline \hline
\end{tabular}

\section{FILTER HARMONIK}

Filter harmonik dibuat untuk mereduksi harmonik - harmonik dengan cara mengurangi amplitudo satu atau lebih frekuensi tertentu dari sebuah tegangan dan arus harmonik. Dengan dipasangnya filter harmonik terhadap sesuatu sistem atau komponen dari sistem tenaga listrik maka penyebaran harmonik ke seluruh jaringan akan ditekan sekecil mungkin. Selain itu filter harmonik dapat memperbaiki nilai faktor daya pada daya listrik. Gambar 4. menunjukkan rangkaian dari sebuah filter harmonik.

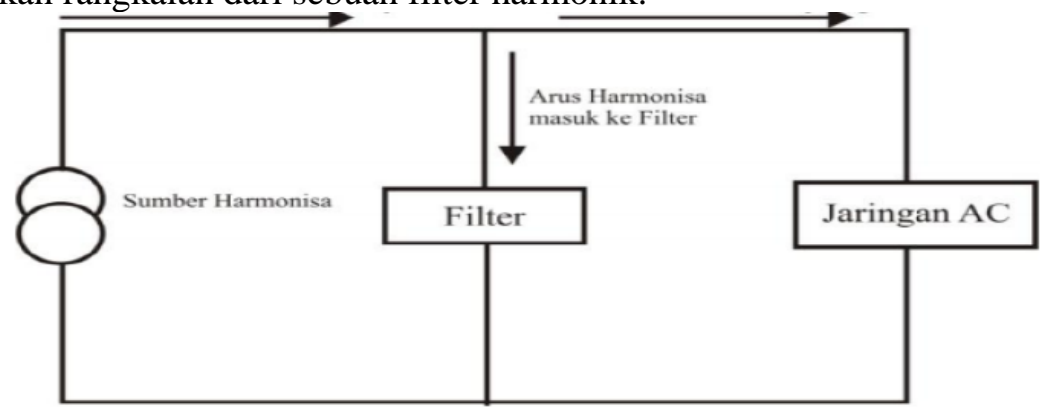

- Gambar 4. Rangkaian filter harmonik

\section{SINGLE TUNED FILTER}

Single Tuned Filter adalah sebuah filter yang hanya mengambil/mereduksi nilai harmonik pada satu frekuensi harmonik saja. Single Tuned Filter ini terdiri dari 2 komponen sederhana yaitu kapasitor yang berfungsi memberi kompensasi daya reaktif untuk memperbaiki nilai faktor daya dan induktor yang menjadi reaktor filter. Besarnya nilai kapasitor dan induktor beserta impedansinya masing - masing yang digunakan untuk merancang Single Tuned Filter adalah sebagai berikut:

Untuk nilai kapasitor dan impedansinya[7]:

$X_{C}=\frac{k V_{\text {rated }}^{2}}{M \text { var }}$.

Keterangan:

$k V_{\text {rated }}=$ Besar rating tegangan 
Mvar $_{\text {rated }}=$ Rating VAR

$C=\frac{1}{2 \pi f X c}$

Keterangan:

$\mathrm{f}=$ Frekuensi fundamental $50 \mathrm{~Hz}$

$X_{C}=$ impedansi kapsitor

Untuk nilai induktor beserta impedansinya:

$X_{L}=\frac{X_{C}}{n^{2}}$

Keterangan:

$\mathrm{Xc}=$ impedansi kapasitor

$\mathrm{N}=$ orde harmonik tegangan yang akan difilter

$L=\frac{X_{L}}{2 \pi f}$

Keterangan:

$X_{L}=$ impedansi induktor

$\mathrm{f}=$ frekuensi fundamental $50 \mathrm{~Hz}$

Untuk orde harmonik tegangan yang akan difilter akan sedikit diturunkan dari nilai orde yang diinginkan. Hal ini dilakukan sebagai toleransi komponen filter untuk mencegah terjadinya resonansi yang terjadi dalam sistem pada frekuensi yang mengganggu[2].

Rumus untuk memperbaiki nilai faktor daya yaitu[7]:

$Q_{V A R}=\sqrt{\frac{\left|P_{1}\right|^{2}}{\left|P F_{0}\right|}-P_{1}^{2}}-\sqrt{\frac{\left|P_{1}\right|^{2}}{|P F|}-P_{1}^{2}}$

Keterangan:

$\mathrm{PF}=$ nilai faktor daya

$P_{1}=$ nilai daya

Single Tuned Filter mempunyai gambar rangkaian yang akan ditunjukkan pada Gambar 5.

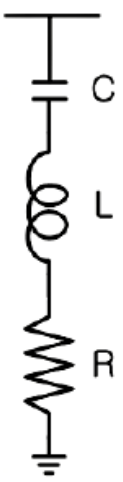

- Gambar 5. Rangkaian Single Tuned Filter [6]

\section{PENGOLAHAN STATISTIK}

Program tersebut akan menghasilkan sebuah keluaran yaitu P-value atau sig. dan taraf signifikansi $(\alpha)$. Pvalue atau sig. adalah merupakan batas kesalahan yang didapat oleh peneliti di dalam melakukan perhitungan statistik yang dipergunakan untuk menolak/menerima hipotesis null $\left(\mathrm{H}_{0}\right)$. Taraf signifikansi $(\alpha)$ adalah batas kesalahan maksimal yang dijadikan tolak ukur oleh peneliti didalam melakukan penelitian untuk menolak/menerima hipotesis null $\left(\mathrm{H}_{0}\right)$. Hipotesis didalam penelitian ini ada dua yaitu $\mathrm{H}_{0}$ dan $\mathrm{H}_{1} \cdot \mathrm{H}_{0}$ adalah hipotesis yang menyimpulkan hubungan yang relevan dari rumusan masalah dan informasi dari data yang dihasilkan dalam penelitian, sedangkan $\mathrm{H}_{1}$ adalah hipotesis alternatif yang dapat digunakan ketika $\mathrm{H}_{0}$ salah.

\section{KERANGKA PIKIR PENELITIAN}

Frekuensi Harmonik adalah gejala pembentukan gelombang sinusoidal baru yang memiliki nilai frekuensi dari hasil perkalian bilangan bulat dengan frekuensi fundamentalnya. Frekuensi Harmonik ini ada karena pengaruh dari beban non-linier. Penelitian menyatakan bahwa beban non-linier merupakan pembangkit harmonik[8]. Beban non-linier merupakan sinyal yang keluar tidak sebanding dengan sinyal yang masuk sehingga terjadi distorsi-distorsi. Beban rumah tangga merupakan beban non-linier. Salah satu distorsi yang terjadi pada beban rumah tangga adalah distorsi harmonik. Distorsi harmonik adalah gangguan harmonik yang membuat frekuensi output tidak sebanding dengan frekuensi input. Distorsi harmonik membuat frekuensi menjadi kelipatan 
dari bilangan bulat dengan frekuensi fundamentalnya. Distorsi harmonik ini membuat nilai faktor daya menurun dan pemakaian daya listrik yang tidak maksimal. Penelitian menyatakan bahwa distorsi harmonik dapat mempengaruhi nilai faktor daya dan rugi daya pada instalasi industri listrik karena arus harmonik dapat membentuk distorsi gelombang tegangan sehingga tidak membentuk sinusoidal murni lagi[8].

Berbagai macam cara dilakukan untuk mereduksi/menghilangkan distorsi harmonik karena dianggap merupakan sebuah gangguan yang sangat merugikan. Salah satu cara untuk mereduksi/menghilangkan distorsi harmonik adalah dengan merancang sebuah filter pasif yang dapat mereduksi distorsi harmonik. Penelitian menyatakan bahwa salah satu upaya untuk mereduksi distorsi harmonik adalah dengan cara merancang sebuah filter pasif karena filter pasif adalah filter yang biasa digunakan untuk mereduksi frekuensi harmonik pada beban non-linier, karena pada perancangannya filter pasif hanya menggunakan komponen R, L dan C[9]. Single Tuned Filter merupakan filter pasif yang dapat mereduksi distorsi harmonik dan menaikkan nilai faktor daya. Filter ini cukup baik untuk beban non - linier. Filter pasif ini akan dipasang pada beban rumah tangga 2200 VA. Pada saat pengukuran dilakukan beban yang menyala ada 3 buah lampu, 1 buah lemari es, 1 buah kipas angin, 1 buah dispenser, dan 1 buah televisi. Filter ini dirancang dengan menggunakan komponen L dan C.

\section{HIPOTESIS PENELITIAN}

1. Penurunan nilai $\mathrm{IHD}_{\mathrm{I}}$ berpengaruh positif terhadap nilai faktor daya.

2. Penurunan nilai $\mathrm{IHD}_{\mathrm{V}}$ berpengaruh positif terhadap nilai faktor daya.

3. Nilai $I H D_{I}$ pada beban rumah tangga yang sudah dipasangi filter memiliki perbedaan yang signifikan daripada nilai $\mathrm{IHD}_{\mathrm{I}}$ pada beban rumah tangga yang belum dipasangi filter.

4. Nilai $\mathrm{IHD}_{\mathrm{V}}$ pada beban rumah tangga yang sudah dipasangi filter memiliki perbedaan yang signifikan daripada nilai $\mathrm{IHD}_{\mathrm{V}}$ pada beban rumah tangga yang belum dipasangi filter.

5. Nilai faktor daya pada beban rumah tangga yang sudah dipasangi filter memiliki perbedaan yang signifikan daripada nilai faktor daya pada beban rumah tangga yang belum dipasangi filter.

\section{TEMPAT DAN WAKTU PENELITIAN}

Penelitian akan dilakukan di Sebuah rumah yang memiliki daya listrik 2200 VA yang terletak di daerah Pondok Kelapa. Penelitian ini akan dilaksanakan dari bulan Maret 2017 sampai bulan Juni 2017.

\section{VARIABEL PENELITIAN}

Variabel penelitian dalam penelitian ini adalah $\mathrm{IHD}_{\mathrm{V}}, \mathrm{IHD}_{\mathrm{I}}$ dan faktor daya. Variabel tersebut dibagi menjadi dua, yaitu:

1. Variabel independen:

- $\mathrm{IHD}_{\mathrm{V}}$

Variabel dependen:

- Faktor daya

2. Variabel independen:

- $\mathrm{IHD}_{\mathrm{I}}$

Variabel dependen:

- Faktor daya

\section{POPULASI DAN SAMPEL}

Populasi dari penelitian ini adalah beban rumah tangga 2200 VA. Teknik pengambilan sampel dibagi menjadi dua, yaitu probability sample dan nonprobability sample. Secara probability merupakan teknik pengambilan sampel dimana setiap populasi mempunyai peluang yang sama untuk menjadi sampel. Secara nonprobability merupakan teknik pengambilan sampel dimana setiap populasi tidak memiliki peluang/kesempatan untuk menjadi sama dengan sampel. Penelitian akan dilakukan secara probability, akan tetapi karena keterbatas waktu dan sampel yang digunakan maka sampel akan diambil 7 di Jakarta Timur.

\section{HIPOTESIS STATISTIK}

Penelitian ini menggunakan pengujian hipotesis koefisien korelasi Pearson Product Moment, pengujian hipotesis statistik parametrik Uji T Berpasangan untuk data terdistribusi normal. Hipotesis statistik dalam penelitian ini terdiri dari Hipotesis nol $\left(\mathrm{H}_{0}\right)$ dan Hipotesis alternatif $\left(\mathrm{H}_{1}\right)$.

1. Hipotesis Statistik Korelasi Pearson Product Moment

Jika P-value $<\alpha$, maka $\mathrm{H}_{0}$ ditolak.

Jika P-value $\geq \alpha$, maka $\mathrm{H}_{0}$ tidak dapat ditolak.

$\mathrm{H}_{0}$ : tidak terdapat pengaruh positif antara penurunan frekuensi harmonik ke-3 pada nilai $\mathrm{IHD}_{\mathrm{I}}$ terhadap nilai faktor daya

$\mathrm{H}_{1}$ : terdapat pengaruh positif antara penurunan frekuensi harmonik ke-3 pada nilai $\mathrm{IHD}_{\mathrm{I}}$ terhadap nilai faktor daya 
P-value: P-value terhitung

$\alpha \quad$ : Taraf signifikansi $(0,05)$

2. Hipotesis Statistik Korelasi Pearson Product Moment

Jika P-value $<\alpha$, maka $\mathrm{H}_{0}$ ditolak.

Jika P-value $\geq \alpha$, maka $\mathrm{H}_{0}$ tidak dapat ditolak.

$\mathrm{H}_{0}$ : tidak terdapat pengaruh positif antara penurunan frekuensi harmonik ke-3 pada nilai $\mathrm{IHD}_{\mathrm{v}}$ terhadap nilai faktor daya

$\mathrm{H}_{1}$ : terdapat pengaruh positif antara penurunan frekuensi harmonik ke-3 pada nilai $\mathrm{IHD}_{\mathrm{v}}$ terhadap nilai faktor daya

P-value: P-value terhitung

$\alpha \quad$ : Taraf signifikansi $(0,05)$

3. Hipotesis Statistik Uji T berpasangan untuk $\mathrm{IHD}_{\mathrm{I}}$

Jika P-value $<\alpha$, maka $\mathrm{H}_{0}$ ditolak.

Jika P-value $\geq \alpha$, maka $\mathrm{H}_{0}$ tidak dapat ditolak.

$\mathrm{H}_{0}$ : tidak terdapat perbedaan yang signifikan antara nilai $\mathrm{IHD}_{\mathrm{I}}$ sebelum dipasangi filter dengan nilai $\mathrm{IHD}_{\mathrm{I}}$ sesudah dipasangi filter.

$\mathrm{H}_{1}$ : terdapat perbedaan yang signifikan antara nilai $\mathrm{IHD}_{\mathrm{I}}$ sebelum dipasangi filter dengan nilai $\mathrm{IHD}_{\mathrm{I}}$ sesudah dipasangi filter.

$\mathrm{P}$-value: $\mathrm{P}$-value terhitung

$\alpha \quad$ : Taraf signifikansi $(0,05)$

4. Hipotesis Statistik Uji T berpasangan untuk $\operatorname{IHD}_{\mathrm{v}}$

Jika P-value $<\alpha$, maka $\mathrm{H}_{0}$ ditolak.

Jika P-value $\geq \alpha$, maka $\mathrm{H}_{0}$ tidak dapat ditolak.

$\mathrm{H}_{0}$ : tidak terdapat perbedaan yang signifikan antara nilai $\mathrm{IHD}_{\mathrm{v}}$ sebelum dipasangi filter dengan nilai $\mathrm{IHD}_{\mathrm{v}}$ sesudah dipasangi filter.

$\mathrm{H}_{1}$ : terdapat perbedaan yang signifikan antara nilai $\mathrm{IHD}_{\mathrm{v}}$ sebelum dipasangi filter

dengan nilai $\mathrm{IHD}_{\mathrm{v}}$ sesudah dipasangi filter.

P-value: P-value terhitung

$\alpha \quad$ : Taraf signifikansi $(0,05)$

5. Hipotesis Statistik Uji T berpasangan untuk nilai faktor daya

Jika P-value $<\alpha$, maka $\mathrm{H}_{0}$ ditolak.

Jika P-value $\geq \alpha$, maka $\mathrm{H}_{0}$ tidak dapat ditolak.

$\mathrm{H}_{0}$ : tidak terdapat perbedaan yang signifikan antara nilai faktor daya sebelum dipasangi filter dengan nilai faktor daya sesudah dipasangi filter.

$\mathrm{H}_{1}$ : terdapat perbedaan yang signifikan antara nilai faktor daya sebelum dipasangi filter dengan nilai faktor daya sesudah dipasangi filter.

P-value: P-value terhitung

$\alpha \quad$ : Taraf signifikansi $(0,05)$

\section{INSTRUMEN PENELITIAN}

Instrumen penelitian yang digunakan adalah HIOKI 3197 Power Quality Analyzer untuk mengukur THD, IHD, Vrms, Irms, dan Faktor daya.

\section{METODE PENGUKURAN}

Metode pengukuran yang digunakan adalah metode observasi, yaitu metode dengan cara melakukan pengumpulan dan pengamatan data secara sistematis dan langsung.

\section{TEKNIK PENGUMPULAN DATA}

Teknik pengumpulan data yang dilakukan adalah dengan menggunakan metode observasi, yaitu cara pengumpulan dan pengamatan data secara sistematis dan langsung. Metode observasi akan diterapkan pada penelitian ini dengan cara melakukan penelitian ditempat dan waktu yang telah direncanakan, lalu melakukan pengukuran dengan alat ukur secara langsung. 
Teknik pengolahan data yang digunakan yaitu dengan melakukan pengeditan data, tabulasi data dan diolah menggunakan software SPSS Statistics 21. Pengeditan data dilakukan setelah data terkumpul kemudian data dikoreksi kembali. Tabulasi data adalah memasukkan data yang didapatkan kedalam sebuah tabel yang sudah dibuat sesuai dengan kebutuhan, lalu diolah dengan menggunakan software SPSS Statistics 21.

\section{PENGUJIAN DAN ANALISIS KESELURUHAN SISTEM PENGUMPULAN DAN VERIFIKASI DATA}

Teknik Pengumpulan data yang dilakukan dalam penelitian ini adalah menggunakan metode observasi. Metode observasi dilaksanakan dengan melakukan penelitian dan pengamatan secara langsung di sebuah rumah di daerah pondok kelapa. Penelitian ini akan menghasilkan sebuah data yang terdiri dari 3 variabel, yaitu $\mathrm{IHD}_{\mathrm{V}}$, $\mathrm{IHD}_{\mathrm{I}}$, dan faktor daya. Data yang dihasilkan akan disusun didalam sebuah tabel, lalu data akan diuji kenormalan data Kolmogorov Smirnov Normality Test untuk mengetahui data tersebut terdistribusi normal atau tidak dan untuk menentukan data akan diuji dengan menggunakan pengujian hipotesis statistik parametrik atau non parametrik. Penelitian ini menggunakan 2 pengujian hipotesis untuk data yang terdistribusi normal yaitu pengujian hipotesis koefisien korelasi Pearson Product Moment dan pengujian hipotesis statistik parametrik Uji T Berpasangan.

\section{PENYAJIAN DAN PENGOLAHAN DATA}

Penyajian dan pengolahan data dalam penelitian ini akan dilakukan setelah semua variabel telah diuji berulang kali. Data disajikan ke dalam sebuah tabel, lalu diolah dengan menggunakan software SPSS Statistics 21. Pengujian dilakukan berulang kali untuk variabel-variabel dalam penelitian ini baik sebelum difilter maupun sesudah difilter.

\section{PERSYARATAN UJI HIPOTESIS KENORMALAN DATA (Liliefors)}

Uji kenormalan data Kolmogorov Smirnov Normally Test dilakukan untuk mengetahui data hasil penelitian ini terdistribusi normal atau tidak serta untuk menentukan pengujian hipotesis parametrik atau non parametrik yang harus digunakan untuk menguji data. Data dapat dikatakan tersdistribusi normal apabila data tersebut memiliki P-value lebih besar dari taraf signifikansi $\alpha$ dan data tidak terdistribusi normal apabila P-value lebih kecil dari taraf signifikansi $\alpha$.

\section{HIPOTESIS UJI KENORMALAN DATA (Liliefors)}

Hipotesis Statistik Uji Kenormalan Data

Jika P-value $<\alpha$, maka $\mathrm{H}_{0}$ ditolak.

Jika P-value $\geq \alpha$, maka $\mathrm{H}_{0}$ tidak dapat ditolak.

$\mathrm{H}_{0}$ : data berasal dari populasi yang terdistribusi normal.

$\mathrm{H}_{1}$ : data tidak berasal dari populasi yang terdistribusi normal.

P-value: P-value terhitung

$\alpha \quad$ : Taraf signifikansi $(0,05)$

\section{PENGUJIAN HIPOTESIS UJI KENORMALAN DATA (Liliefors)}

Pengujian hipotesis uji kenormalan data dilakukan untuk variabel-variabel dalam penelitian ini yaitu $\mathrm{IHD}_{\mathrm{V}}, \mathrm{IHD}_{\mathrm{I}}$, dan faktor daya sebelum dipasangi filter. Pengujian hipotesis uji kenormalan data juga dilakukan untuk variabel-variabel $\mathrm{IHD}_{\mathrm{V}}, \mathrm{IHD}_{\mathrm{I}}$, dan faktor daya sesudah dipasangi filter untuk mengetahui pengujian statistik parametrik atau non paramterik yang akan digunakan. Hasil pengukuran pada beban rumah tangga 2200 VA sebelum dipasangi filter dapat dilihat pada tabel 3.

Tabel 3. Hasil Pengukuran Beban Rumah Tangga 2200 VA sebelum dipasangi filter

\begin{tabular}{|c|c|c|c|c|c|}
\hline No. & Sampel & Waktu & $\begin{array}{c}\mathrm{IHD}_{\mathrm{I}} \\
\text { Orde ke-3 }\end{array}$ & $\begin{array}{c}\mathrm{IHD}_{\mathrm{V}} \\
\text { Orde ke-3 }\end{array}$ & $\begin{array}{c}\text { Power } \\
\text { Factor }\end{array}$ \\
\hline 1 & Rumah 1 & 09.00 & 4.08 & 1.57 & 0.87 \\
\hline 2 & Rumah 1 & 14.00 & 4.06 & 1.58 & 0.82 \\
\hline 3 & Rumah 1 & 19.00 & 3.78 & 1.79 & 0.83 \\
\hline 4 & Rumah 2 & 09.00 & 2.71 & 1.90 & 0.88 \\
\hline 5 & Rumah 2 & 14.00 & 3.60 & 1.74 & 0.87 \\
\hline 6 & Rumah 2 & 19.00 & 2.41 & 1.44 & 0.90 \\
\hline
\end{tabular}


Randy, Endah Setyaningsih, dan Tjandra Susila

\begin{tabular}{|l|l|l|l|l|l|}
\hline 7 & Rumah 3 & 09.00 & 3.54 & 1.58 & 0.89 \\
\hline 8 & Rumah 3 & 14.00 & 3.74 & 1.68 & 0.81 \\
\hline 9 & Rumah 3 & 19.00 & 3.07 & 1.76 & 0.85 \\
\hline 10 & Rumah 4 & 09.00 & 4.20 & 2.03 & 0.84 \\
\hline 11 & Rumah 4 & 14.00 & 3.93 & 1.94 & 0.84 \\
\hline 12 & Rumah 4 & 19.00 & 4.89 & 1.64 & 0.83 \\
\hline 13 & Rumah 5 & 09.00 & 7.68 & 1.68 & 0.86 \\
\hline 14 & Rumah 5 & 14.00 & 7.37 & 1.73 & 0.83 \\
\hline 15 & Rumah 5 & 19.00 & 4.79 & 1.75 & 0.83 \\
\hline 16 & Rumah 6 & 09.00 & 8.88 & 1.74 & 0.88 \\
\hline 17 & Rumah 6 & 14.00 & 9.35 & 1.77 & 0.81 \\
\hline 18 & Rumah 6 & 19.00 & 6.85 & 1.84 & 0.85 \\
\hline 19 & Rumah 7 & 09.00 & 9.01 & 1.67 & 0.84 \\
\hline 20 & Rumah 7 & 14.00 & 8.79 & 1.49 & 0.83 \\
\hline 21 & Rumah 7 & 19.00 & 8.82 & 1.70 & 0.83 \\
\hline
\end{tabular}

Berdasarkan Tabel 4.1. dapat dilihat bahwa variabel-variabel di atas, yaitu $\mathrm{IHD}_{\mathrm{V}}, \mathrm{IHD}_{\mathrm{I}}$, dan faktor daya memiliki data yang bervariasi. Data yang bervariasi ini disebabkan oleh seiring berjalannya waktu terjadi perubahan tegangan, arus, dan nilai faktor daya yang berubah-ubah sesuai dengan kebutuhan yang digunakan. Penelitian ini menggunakan filter pasif Single Tuned Filter untuk mereduksi frekuensi harmonik ke-3 pada suatu beban rumah tangga 2200 VA. Tabel 4 menunjukkan Hasil Pengukuran Beban Rumah Tangga 2200 VA sesudah dipasangi filter.

Tabel 4. Hasil Pengukuran Beban Rumah Tangga 2200 VA sesudah dipasangi filter

\begin{tabular}{|c|c|c|c|c|c|}
\hline No. & Sampel & Waktu & $\begin{array}{c}\text { IHD }_{\mathrm{I}} \\
\text { Orde ke-3 }\end{array}$ & $\begin{array}{c}\mathrm{IHD}_{\mathrm{V}} \\
\text { Orde ke-3 }\end{array}$ & $\begin{array}{c}\text { Power } \\
\text { Factor }\end{array}$ \\
\hline 1 & Rumah 1 & 09.00 & 2.05 & 0.49 & 0.98 \\
\hline 2 & Rumah 1 & 14.00 & 2.84 & 0.57 & 0.97 \\
\hline 3 & Rumah 1 & 19.00 & 3.64 & 0.43 & 0.97 \\
\hline 4 & Rumah 2 & 09.00 & 2.82 & 0.25 & 0.97 \\
\hline 5 & Rumah 2 & 14.00 & 3.58 & 0.59 & 0.98 \\
\hline 6 & Rumah 2 & 19.00 & 2.35 & 0.75 & 0.99 \\
\hline 7 & Rumah 3 & 09.00 & 3.61 & 0.66 & 0.99 \\
\hline 8 & Rumah 3 & 14.00 & 3.55 & 0.57 & 0.98 \\
\hline 9 & Rumah 3 & 19.00 & 2.64 & 0.63 & 0.97 \\
\hline 10 & Rumah 4 & 09.00 & 3.68 & 0.85 & 0.98 \\
\hline 11 & Rumah 4 & 14.00 & 2.89 & 0.94 & 0.99 \\
\hline 12 & Rumah 4 & 19.00 & 1.32 & 0.76 & 0.99 \\
\hline 13 & Rumah 5 & 09.00 & 2.16 & 0.90 & 0.98 \\
\hline 14 & Rumah 5 & 14.00 & 2.11 & 0.97 & 0.98 \\
\hline 15 & Rumah 5 & 19.00 & 1.98 & 1.01 & 0.97 \\
\hline 16 & Rumah 6 & 09.00 & 5.17 & 0.97 & 0.99 \\
\hline & & & & & \\
\hline
\end{tabular}




\begin{tabular}{|l|l|l|l|l|l|}
\hline 17 & Rumah 6 & 14.00 & 5.19 & 1.00 & 0.97 \\
\hline 18 & Rumah 6 & 19.00 & 3.69 & 0.91 & 0.98 \\
\hline 19 & Rumah 7 & 09.00 & 4.58 & 1.06 & 0.98 \\
\hline 20 & Rumah 7 & 14.00 & 4.38 & 1.05 & 0.98 \\
\hline 21 & Rumah 7 & 19.00 & 4.64 & 1.18 & 0.97 \\
\hline
\end{tabular}

Hasil Uji Kenormalan data $\mathrm{IHD}_{\mathrm{V}}$ sebelum dipasangi Single Tuned Filter dapat dilihat pada Gambar 6. Hasil Uji Kenormalan data $\mathrm{IHD}_{\mathrm{I}}$ sebelum dipasangi Single Tuned Filter dapat dilihat pada Gambar 7 Hasil Uji Kenormalan data nilai faktor daya (Power Factor) sebelum dipasangi Single Tuned Filter dapat dilihat pada Gambar 8.

Tests of Normality

\begin{tabular}{|c|c|c|c|c|c|c|}
\hline & \multicolumn{3}{|c|}{ Kolmogorov-Smirnov ${ }^{\mathrm{a}}$} & \multicolumn{3}{|c|}{ Shapiro-Wilk } \\
\hline & Statistic & df & Sig. & Statistic & $\mathrm{df}$ & Sig. \\
\hline IHDi & .147 & 25 & .173 & .929 & 25 & .084 \\
\hline
\end{tabular}

- Gambar 6. Hasil Uji Kenormalan data $\mathrm{IHD}_{\mathrm{V}}$ sebelum dipasangi Single Tuned Filter

Kesimpulan dari Gambar 6 adalah nilai P-value $=0.173$ yang mengartikan bahwa nilai P-value lebih besar dari nilai taraf signifikansi $(\alpha)$ yaitu $=0.05$ maka $\mathrm{H}_{0}$ diterima sehingga data terdistribusi normal.

Tests of Normality

\begin{tabular}{|c|c|c|c|c|c|c|}
\hline & \multicolumn{3}{|c|}{ Kolmogorov-Smirnov $^{\mathrm{a}}$} & \multicolumn{3}{|c|}{ Shapiro-Wilk } \\
\hline & Statistic & $\mathrm{df}$ & Sig. & Statistic & $\mathrm{df}$ & Sig. \\
\hline$\overline{\mathrm{IHDV}}$ & .152 & 24 & .078 & .941 & 24 & .175 \\
\hline
\end{tabular}

- Gambar 7. Hasil Uji Kenormalan data $\mathrm{THD}_{\mathrm{I}}$ sebelum dipasangi Single Tuned Filter

Kesimpulan dari Gambar 7 adalah nilai P-value $=0.078$ yang mengartikan bahwa nilai P-value lebih besar dari nilai taraf signifikansi $(\alpha)$ yaitu $=0.05$ maka $\mathrm{H}_{0}$ diterima sehingga data terdistribusi normal.

Tests of Normality

\begin{tabular}{|l|r|r|r|r|r|r|}
\hline & \multicolumn{3}{|c|}{ Kolmogorov-Smirnov $^{\mathrm{a}}$} & \multicolumn{3}{c|}{ Shapiro-Wilk } \\
\cline { 2 - 7 } & Statistic & \multicolumn{1}{|c|}{$\mathrm{df}$} & \multicolumn{1}{c|}{ Sig. } & Statistic & df & \multicolumn{1}{c|}{ Sig. } \\
\hline PowerFactor & .167 & 25 & .069 & .925 & 25 & .066 \\
\hline
\end{tabular}

Gambar 8. Hasil Uji Kenormalan data nilai faktor daya sebelum dipasangi Single Tuned Filter

Kesimpulan dari Gambar 8. adalah nilai P-value $=0.069$ yang mengartikan bahwa nilai $\mathrm{P}$-value lebih besar dari nilai taraf signifikansi $(\alpha)$ yaitu $=0.05$ maka $\mathrm{H}_{0}$ diterima sehingga data terdistribusi normal.

Hasil Uji Kenormalan data $\mathrm{IHD}_{\mathrm{V}}$ sesudah dipasangi Single Tuned Filter dapat dilihat pada Gambar 9. Hasil Uji Kenormalan data $\mathrm{IHD}_{\mathrm{I}}$ sesudah dipasangi Single Tuned Filter dapat dilihat pada Gambar 10. Hasil Uji Kenormalan data nilai faktor daya (Power Factor) sesudah dipasangi Single Tuned Filter dapat dilihat pada Gambar 11.

Tests of Normality

\begin{tabular}{|l|r|r|r|r|r|r|}
\hline \multirow{2}{*}{} & \multicolumn{3}{|c|}{ Kolmogorov-Smirnov $^{\mathrm{a}}$} & \multicolumn{3}{c|}{ Shapiro-Wilk } \\
\cline { 2 - 7 } & Statistic & \multicolumn{1}{c|}{$\mathrm{df}$} & \multicolumn{1}{c|}{ Sig. } & Statistic & \multicolumn{1}{c|}{ df } & \multicolumn{1}{c|}{ Sig. } \\
\hline IHDi & .147 & 25 & .171 & .961 & & 25 \\
\hline
\end{tabular}

Gambar 9. Hasil Uji Kenormalan data $\mathrm{IHD}_{\mathrm{V}}$ sesudah dipasangi Single Tuned Filter

Kesimpulan dari Gambar 9. adalah nilai P-value $=0.171$ yang mengartikan bahwa nilai P-value lebih besar dari nilai taraf signifikansi $(\alpha)$ yaitu $=0.05$ maka $\mathrm{H}_{0}$ diterima sehingga data terdistribusi normal. 
Tests of Normality

\begin{tabular}{|l|r|r|r|r|r|r|}
\hline \multirow{2}{*}{} & \multicolumn{3}{|c|}{ Kolmogorov-Smirnov $^{\mathrm{a}}$} & \multicolumn{3}{c|}{ Shapiro-Wilk } \\
\cline { 2 - 7 } & Statistic & \multicolumn{1}{c|}{$\mathrm{df}$} & \multicolumn{1}{c|}{ Sig. } & Statistic & df & \multicolumn{1}{c|}{ Sig. } \\
\hline IHDv & .152 & 24 & .158 & .941 & 24 & .175 \\
\hline
\end{tabular}

- Gambar 10. Hasil Uji Kenormalan data $\mathrm{IHD}_{\mathrm{I}}$ sesudah dipasangi Single Tuned Filter

Kesimpulan dari Gambar 10. adalah nilai P-value $=0.158$ yang mengartikan bahwa nilai $\mathrm{P}$-value lebih besar dari nilai taraf signifikansi $(\alpha)$ yaitu $=0.05$ maka $\mathrm{H}_{0}$ diterima sehingga data terdistribusi normal.

Tests of Normality

\begin{tabular}{|l|r|r|r|r|r|r|}
\hline & \multicolumn{3}{|c|}{ Kolmogorov-Smirnov $^{\mathrm{a}}$} & \multicolumn{3}{c|}{ Shapiro-Wilk } \\
\cline { 2 - 7 } & Statistic & $\mathrm{df}$ & \multicolumn{1}{c|}{ Sig. } & Statistic & $\mathrm{df}$ & \multicolumn{1}{c|}{ Sig. } \\
\hline PowerFactor & .366 & 24 & .061 & .735 & 24 & .000 \\
\hline
\end{tabular}

Gambar 11. Hasil Uji Kenormalan data nilai faktor daya sebelum dipasangi Single Tuned Filter

Kesimpulan dari Gambar 11 adalah nilai P-value $=0.061$ yang mengartikan bahwa nilai P-value lebih besar dari nilai taraf signifikansi $(\alpha)$ yaitu $=0.05$ maka $\mathrm{H}_{0}$ diterima sehingga data terdistribusi normal.

\section{PENGUJIAN HIPOTESIS STATISTIK KORELASI PEARSON PRODUCT MOMENT UNTUK PENGARUH PENURUNAN NILAI IHD I ORDE KE-3 TERHADAP FAKTOR DAYA}

Pengujian hipotesis statistik korelasi Pearson Product Moment ini bertujuan untuk mengetahui apakah variabel $\mathrm{IHD}_{\mathrm{I}}$ terdapat hubungan positif/negatif atau tidak memiliki hubungan dengan variabel faktor daya. Data tersebut merupakan data yang terdistribusi normal. Hasil dari Pengujian Hipotesis statistik ini merupakan sebuah koefisien korelasi r yang memiliki arti tersendiri dari setiap nominalnya. Koefisien korelasi terletak antara -1 dan 1 , yaitu $-1 \leq 1$. Jika nilai $r=-1$ merupakan korelasi linier negatif (berlawanan arah) maka terdapat hubungan yang negatif antara variabel $\mathrm{IHD}_{\mathrm{I}}$ dengan variable faktor daya. Jika nilai $\mathrm{r}=1$ merupakan korelasi koefisien positif (searah) maka terdapat hubungan yang positif antara penurunan frekuensi harmonik ke-3 pada nilai variabel IHD $_{\mathrm{I}}$ terhadap variabel nilai faktor daya dan jika nilai $r=0$ merupakan tidak ada korelasi linier maka tidak terdapat hubungan apapun antara penurunan frekuensi harmonik ke-3 pada nilai variabel $\mathrm{IHD}_{\mathrm{I}}$ terhadap variabel faktor daya.

Arti dari koefisien korelasi r:

1. Jika $0,9<\mathrm{r}<1,0$ atau $-1,0<\mathrm{r}<-0,9$ berarti memiliki hubungan yang sangat kuat.

2. Jika $0,7<\mathrm{r}<0,9$ atau $-0,9<\mathrm{r}<-0,7$ berarti memiliki hubungan yang kuat.

3. Jika $0,5<\mathrm{r}<0,7$ atau $-0,7<\mathrm{r}<-0,5$ berarti memiliki hubungan yang cukup.

4. Jika $0,3<\mathrm{r}<0,5$ atau $-0,5<\mathrm{r}<-0,3$ berarti memiliki hubungan yang lemah.

5. Jika $0<\mathrm{r}<0,3$ atau $-0,3<\mathrm{r}<0$ berarti memiliki hubungan yang sangat lemah.

Gambar 12.

Hasil Pengujian hipotesis statistik korelasi variabel $\mathrm{IHD}_{\mathrm{I}}$ terhadap variabel faktor daya dapat dilihat pada

\begin{tabular}{|cc|c|c|}
\hline \multicolumn{4}{c}{ Correlations } \\
\hline \multirow{3}{*}{ IHDi } & Pearson Correlation & 1 & .565 \\
& Sig. (2-tailed) & & .031 \\
& $\mathrm{~N}$ & 21 & 21 \\
& Pearson Correlation & .565 & 1 \\
PowerFactor & Sig. (2-tailed) & .031 & \\
& $\mathrm{~N}$ & 21 & 21 \\
\hline
\end{tabular}

Gambar 12. Hasil pengujian hipotesis statistik koefisien korelasi $\mathrm{THD}_{\mathrm{I}}$ terhadap faktor daya

Berdasarkan Gambar 12 dapat disimpulkan bahwa P-value $=0.031$ yaitu lebih kecil dari nilai taraf signifikansi $=0,05$ maka $\mathrm{H}_{0}$ ditolak sehingga terdapat pengaruh positif antara penurunan frekuensi harmonik ke3 pada nilai variabel $\mathrm{IHD}_{\mathrm{I}}$ terhadap faktor daya. Korelasi antara variabel $\mathrm{IHD}_{\mathrm{I}}$ dengan variabel faktor daya $=0.565$ memiliki pengaruh positif yang cukup kuat.

PENGUJIAN HIPOTESIS STATISTIK KORELASI PEARSON PRODUCT MOMENT UNTUK PENGARUH PENURUNAN NILAI IHD $_{V}$ ORDE KE-3 TERHADAP FAKTOR DAYA 
Pengujian hipotesis statistik korelasi Pearson Product Moment ini bertujuan untuk mengetahui apakah penurunan frekuensi harmonik ke-3 pada variabel $I H D_{V}$ terdapat hubungan positif/negatif atau tidak memiliki hubungan dengan variabel faktor daya. Data tersebut merupakan data yang terdistribusi normal. Hasil Pengujian hipotesis statistik korelasi variabel $\mathrm{IHD}_{\mathrm{V}}$ terhadap variabel faktor daya dapat dilihat pada Gambar 13.

Correlations

\begin{tabular}{|cc|c|c|}
\hline & & IHDv & PowerFactor \\
\hline \multirow{4}{*}{ IHDv } & Pearson Correlation & 1 & .507 \\
& Sig. (2-tailed) & & .036 \\
& $\mathrm{~N}$ & 21 & 21 \\
PowerFactor & Pearson Correlation & .507 & 1 \\
& Sig. (2-tailed) & .036 & \\
& $\mathrm{~N}$ & 21 & 21 \\
\hline
\end{tabular}

Gambar 13. Hasil pengujian hipotesis statistik koefisien korelasi $\mathrm{IHD}_{\mathrm{V}}$ terhadap faktor daya

Berdasarkan Gambar 13. dapat disimpulkan bahwa P-value $=0.036$ yaitu lebih kecil dari nilai taraf signifikansi $=0,05$ maka $\mathrm{H}_{0}$ ditolak sehingga terdapat pengaruh positif antara penurunan frekuensi harmonik ke3 pada variabel $\mathrm{IHD}_{\mathrm{V}}$ terhadap nilai faktor daya. Korelasi antara variabel $\mathrm{IHD}_{\mathrm{V}}$ dengan variabel faktor daya $=$ 0.507 memiliki pengaruh positif yang cukup kuat.

\section{PENGUJIAN HIPOTESIS STATISTIK UJI T BERPASANGAN UNTUK IHD I SEBELUM

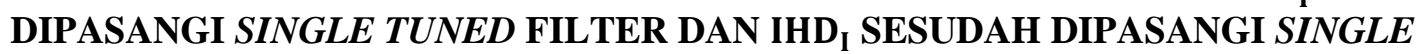 TUNED FILTER}

Pengujian Hipotesis Statistik Uji T berpasangan untuk variabel $\mathrm{IHD}_{\mathrm{I}}$ sebelum dipasangi Single Tuned Filter dan sesudah dipasangi Single Tuned Filter karena variabel $\mathrm{IHD}_{\mathrm{I}}$ memiliki data yang terdistribusi normal baik sebelum ataupun sesudah dipasangi Single Tuned Filter. Hasil Pengujian Hipotesis Statistik Uji T berpasangan Untuk $\mathrm{IHD}_{\mathrm{I}}$ sebelum dipasangi Single Tuned Filter dan sesudah dipasangi Single Tuned Filter dapat dilihat pada Gambar 14. dan Gambar 15.

Paired Samples Statistics

\begin{tabular}{|rr|r|r|r|c|}
\hline & Mean & $\mathrm{N}$ & $\begin{array}{c}\text { Std. } \\
\text { Deviation }\end{array}$ & $\begin{array}{c}\text { Std. Error } \\
\text { Mean }\end{array}$ \\
\hline Pair 1 & IHDi Sebelum & 5.8852 & 21 & 2.09328 & .41866 \\
& IHDi Sesudah & 2.9820 & 21 & 1.13387 & .22677 \\
\hline
\end{tabular}

Gambar 14. Hasil Pengujian Hipotesis Statistik untuk $\mathrm{IHD}_{\mathrm{I}}$ sebelum dipasangi filter dan sesudah dipasangi filter

Paired Samples Test

\begin{tabular}{|c|c|c|c|c|c|c|c|c|}
\hline & \multicolumn{5}{|c|}{ Paired Differences } & \multirow[t]{3}{*}{$\mathrm{t}$} & \multirow[t]{3}{*}{$\mathrm{df}$} & \multirow{3}{*}{$\begin{array}{l}\text { Sig. (2- } \\
\text { tailed) }\end{array}$} \\
\hline & \multirow[t]{2}{*}{$\begin{array}{c}\text { Mea } \\
\mathrm{n}\end{array}$} & \multirow[t]{2}{*}{$\begin{array}{l}\text { Std. } \\
\text { Deviati } \\
\text { on }\end{array}$} & \multirow[t]{2}{*}{$\begin{array}{l}\text { Std. } \\
\text { Error } \\
\text { Mean }\end{array}$} & \multicolumn{2}{|c|}{$\begin{array}{l}\text { 95\% Confidence } \\
\text { Interval of the } \\
\text { Difference }\end{array}$} & & & \\
\hline & & & & Lower & Upper & & & \\
\hline $\begin{array}{ll}\text { Pai } & \text { IHDi } \\
\text { r 1 } & \text { Sebelum - } \\
\text { IHDi Sesudah }\end{array}$ & $\begin{array}{r}2.90 \\
320\end{array}$ & $\begin{array}{r}1.2185 \\
8\end{array}$ & .24372 & $\begin{array}{r}2.4002 \\
0\end{array}$ & $\begin{array}{r}3.4062 \\
0\end{array}$ & $\begin{array}{r}11.9 \\
12\end{array}$ & 24 & .000 \\
\hline
\end{tabular}

Gambar 15. Hasil Pengujian Hipotesis Statistik untuk $\mathrm{IHD}_{\mathrm{I}}$ sebelum dipasangi filter dan sesudah dipasangi filter (lanjutan)

Kesimpulan dari Gambar 14. adalah bahwa rata-rata $\mathrm{IHD}_{\mathrm{I}}$ sebelum difilter $=5.8852$ dan rata-rata $\mathrm{IHD}_{\mathrm{I}}$ setelah difilter $=2.9820$. Kesimpulan dari Gambar 4.10. adalah bahwa nilai P-value $=0$ yaitu nilai P-value lebih

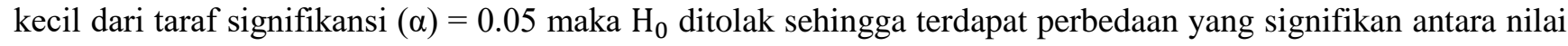
$\mathrm{IHD}_{\mathrm{I}}$ sebelum dipasangi filter dan nilai $\mathrm{IHD}_{\mathrm{I}}$ sesudah dipasangi filter. 


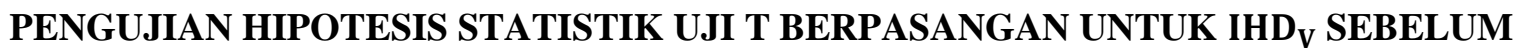

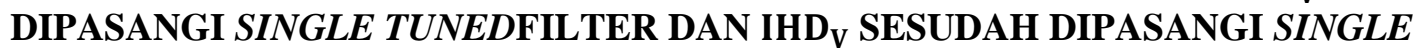 TUNED FILTER}

Pengujian Hipotesis Statistik Uji T berpasangan untuk variabel $\mathrm{IHD}_{\mathrm{V}}$ sebelum dipasangi Single Tuned Filter dan sesudah dipasangi Single Tuned Filter karena variabel $\mathrm{IHD}_{\mathrm{V}}$ memiliki data yang terdistribusi normal baik sebelum ataupun sesudah dipasangi Single Tuned Filter. Hasil Pengujian Hipotesis Statistik Uji T berpasangan Untuk $\mathrm{IHD}_{\mathrm{V}}$ sebelum dipasangi Single Tuned Filter dan sesudah dipasangi Single Tuned Filter dapat dilihat pada Gambar 16. dan Gambar 17.

\section{Paired Samples Statistics}

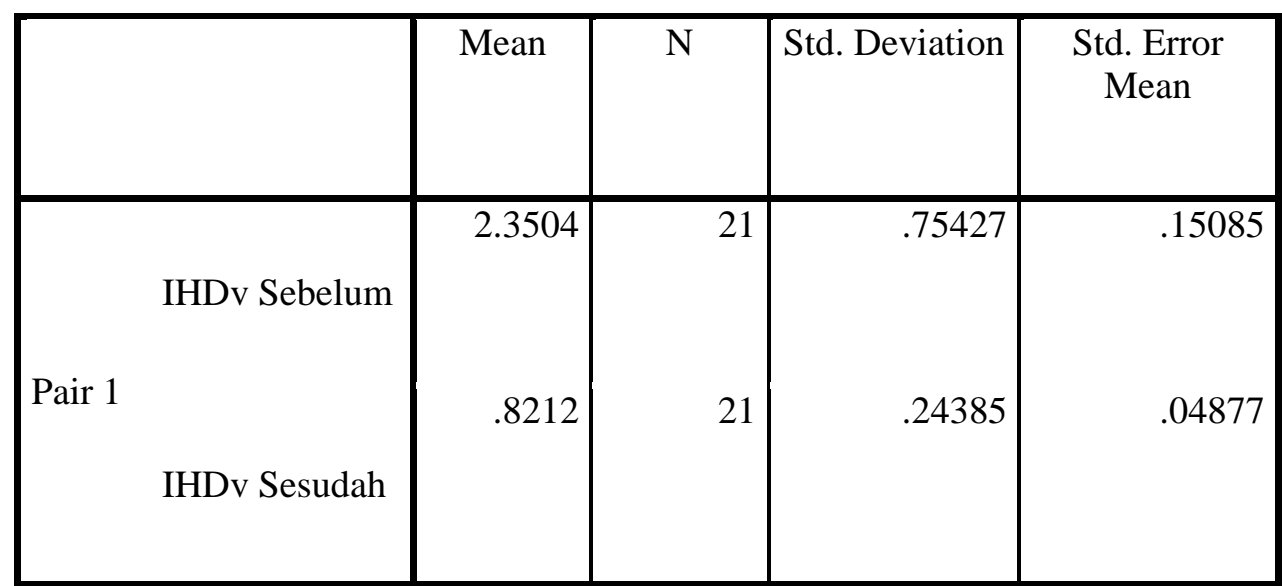

Gambar 16. Hasil Pengujian Hipotesis Statistik untuk $\mathrm{IHD}_{\mathrm{V}}$ sebelum dipasangi filter dan sesudah dipasangi filter

Paired Samples Test

\begin{tabular}{|c|c|c|c|c|c|c|c|c|}
\hline & \multicolumn{5}{|c|}{ Paired Differences } & \multirow[t]{3}{*}{$\mathrm{t}$} & \multirow[t]{3}{*}{$\mathrm{df}$} & \multirow{3}{*}{$\begin{array}{l}\text { Sig. (2- } \\
\text { tailed) }\end{array}$} \\
\hline & \multirow[t]{2}{*}{$\begin{array}{c}\text { Mea } \\
n\end{array}$} & \multirow[t]{2}{*}{$\begin{array}{l}\text { Std. } \\
\text { Deviati } \\
\text { on }\end{array}$} & \multirow[t]{2}{*}{$\begin{array}{l}\text { Std. } \\
\text { Error } \\
\text { Mean }\end{array}$} & \multicolumn{2}{|c|}{$\begin{array}{l}95 \% \text { Confidence } \\
\text { Interval of the } \\
\text { Difference } \\
\end{array}$} & & & \\
\hline & & & & Lower & Upper & & & \\
\hline $\begin{array}{ll}\text { Pai } & \text { IHDv } \\
\text { r1 } & \text { Sebelum } \\
\text { IHDv Sesudah }\end{array}$ & $\begin{array}{r}1.52 \\
920\end{array}$ & .81396 & .16279 & 1.19322 & 1.86518 & $\begin{array}{r}9.39 \\
4\end{array}$ & 24 & .000 \\
\hline
\end{tabular}

- Gambar 17. Hasil Pengujian Hipotesis Statistik untuk $\mathrm{IHD}_{\mathrm{V}}$ sebelum dipasangi filter dan sesudah dipasangi filter (lanjutan)

Kesimpulan dari Gambar 16. adalah bahwa rata-rata $\mathrm{IHD}_{\mathrm{V}}$ sebelum difilter $=2.3504$ dan rata-rata $\mathrm{IHD}_{\mathrm{V}}$ setelah difilter $=0.8212$. Kesimpulan dari Gambar 4.12. adalah bahwa nilai P-value $=0$ yaitu nilai P-value lebih

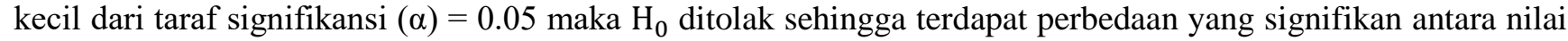
$\mathrm{IHD}_{\mathrm{V}}$ sebelum dipasangi filter dan nilai $\mathrm{IHD}_{\mathrm{V}}$ sesudah dipasangi filter.

\section{PENGUJIAN HIPOTESIS STATISTIK UJI T BERPASANGAN UNTUK FAKTOR DAYA SEBELUM DIPASANGI SINGLE TUNED FILTER DAN FAKTOR DAYA SESUDAH DIPASANGI SINGLE TUNED FILTER}

Pengujian Hipotesis Statistik Uji T berpasangan untuk variabel Faktor daya sebelum dipasangi Single Tuned Filter dan sesudah dipasangi Single Tuned Filter karena variabel Faktor Daya memiliki data yang terdistribusi normal baik sebelum ataupun sesudah dipasangi Single Tuned Filter. Hasil Pengujian Hipotesis Statistik Uji T berpasangan Untuk Faktor Daya sebelum dipasangi Single Tuned Filter dan sesudah dipasangi Single Tuned Filter dapat dilihat pada Gambar 18. dan Gambar 19.

\section{Paired Samples Statistics}

\begin{tabular}{|l|l|l|l|c|}
\hline & Mean & N & Std. Deviation & $\begin{array}{c}\text { Std. Error } \\
\text { Mean }\end{array}$ \\
\hline
\end{tabular}




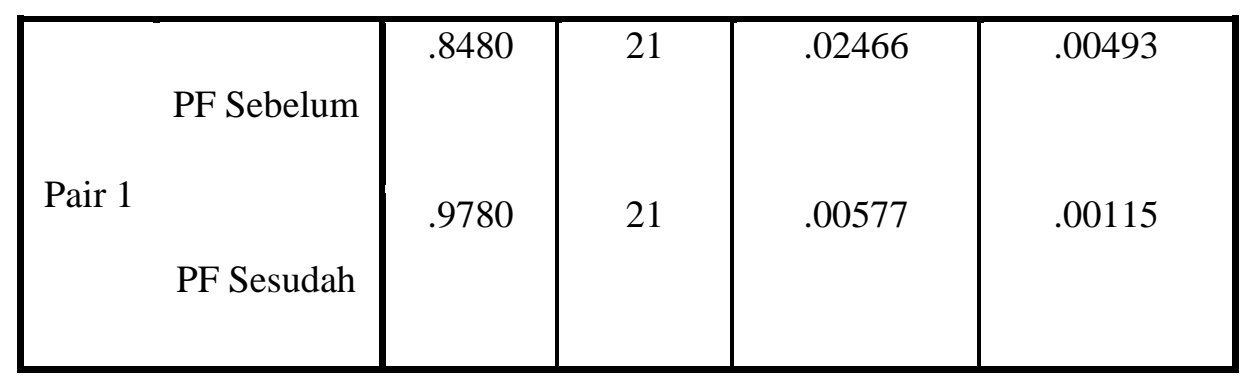

Gambar 18. Hasil Pengujian Hipotesis Statistik untuk Faktor Daya sebelum dipasangi filter dan sesudah dipasangi filter

Paired Samples Test

\begin{tabular}{|c|c|c|c|c|c|c|c|c|}
\hline & \multicolumn{5}{|c|}{ Paired Differences } & \multirow[t]{3}{*}{$\mathrm{t}$} & \multirow[t]{3}{*}{$\mathrm{df}$} & \multirow{3}{*}{$\begin{array}{l}\text { Sig. (2- } \\
\text { tailed) }\end{array}$} \\
\hline & \multirow[t]{2}{*}{$\begin{array}{c}\text { Mea } \\
n\end{array}$} & \multirow[t]{2}{*}{$\begin{array}{c}\text { Std. } \\
\text { Deviati } \\
\text { on }\end{array}$} & \multirow[t]{2}{*}{$\begin{array}{l}\text { Std. } \\
\text { Error } \\
\text { Mean }\end{array}$} & \multicolumn{2}{|c|}{$\begin{array}{l}\text { 95\% Confidence } \\
\text { Interval of the } \\
\text { Difference }\end{array}$} & & & \\
\hline & & & & Lower & Upper & & & \\
\hline $\begin{array}{ll}\text { Pai } & \text { PF Sebelum - } \\
\text { r } 1 & \text { PF Sesudah }\end{array}$ & $\begin{array}{r}-.13 \\
000\end{array}$ & .02828 & .00566 & -.14168 & -.11832 & $\begin{array}{r}- \\
22.9 \\
81\end{array}$ & 24 & .000 \\
\hline
\end{tabular}

Gambar 19. Hasil Pengujian Hipotesis Statistik untuk Faktor Daya sebelum dipasangi filter dan sesudah dipasangi filter (lanjutan)

Kesimpulan dari Gambar 18. adalah bahwa rata-rata Faktor Daya sebelum difilter $=0.8480$ dan rata-rata Faktor Daya setelah difilter $=0.9780$. Kesimpulan dari Gambar 19 adalah bahwa nilai P-value $=0$ yaitu nilai Pvalue lebih kecil dari taraf signifikansi $(\alpha)=0.05$ maka $\mathrm{H}_{0}$ ditolak sehingga terdapat perbedaan yang signifikan antara nilai faktor daya sebelum dipasangi filter dan nilai faktor daya sesudah dipasangi filter.

\section{PEMBAHASAN}

Uji kenormalan data (liliefors) pada $\mathrm{THD}_{\mathrm{I}}$ dan faktor daya menunjukkan bahwa data dari variabel $\mathrm{THD}_{\mathrm{I}}$ dan variabel faktor daya terdistribusi normal sehingga menggunakan pengujian hipotessis statistik Korelasi Pearson Product Moment. Hasil dari Pengujian hipotesis statistik adalah bahwa Korelasi antara variabel IHD $_{\text {I }}$ dengan variabel faktor daya $=0.565$ maka hubungan diantara kedua variabel memiliki pengaruh positif yang cukup kuat. Nilai korelasi tersebut menunjukkan bahwa semakin kecil nilai $\mathrm{IHD}_{\mathrm{I}}$ maka semakin tinggi nilai faktor daya. Pengujian Hipotesis Statistik untuk $\mathrm{IHD}_{\mathrm{V}}$ dan faktor daya menggunakan korelasi Pearson Product Moment dikarenakan kedua variabel memiliki data yang terdistribusi normal. Hasil dari Pengujian Hipotesis Statistik adalah adanya Korelasi antara variabel $\mathrm{IHD}_{\mathrm{V}}$ dengan variabel faktor daya $=0.507$ sehingga memiliki pengaruh positif yang cukup kuat. Koefisien korelasi tersebut menunjukkan bahwa semakin kecil nilai $\mathrm{IHD}_{\mathrm{V}}$ maka semakin tinggi nilai faktor daya.

Hasil dari Pengujian Hipotesis Statistik Uji T berpasangan untuk variabel $\mathrm{IHD}_{\mathrm{I}}$ sebelum dipasangi Single Tuned Filter dan sesudah dipasangi Single Tuned Filter adalah bahwa rata-rata $\mathrm{IHD}_{\mathrm{I}}$ sebelum difilter $=5.8852$ dan rata-rata $I H D_{I}$ setelah difilter $=2.9820$ dari hasil rata-rata ini disimpulkan bahwa nilai $I_{H} D_{I}$ sesudah difilter lebih kecil dibandingkan dengan nilai $\mathrm{IHD}_{\mathrm{I}}$ sebelum difilter. Nilai $\mathrm{IHD}_{\mathrm{I}}$ telah tereduksi sesudah difilter. Hasil dari Pengujian Hipotesis Statistik Uji T berpasangan untuk variabel $\mathrm{IHD}_{\mathrm{V}}$ sebelum dipasangi Single Tuned Filter dan sesudah dipasangi Single Tuned Filter bahwa rata-rata $\mathrm{IHD}_{\mathrm{V}}$ sebelum difilter $=2.3504$ dan rata-rata $\mathrm{IHD}_{\mathrm{V}}$ setelah difilter $=0.8212$ dari hasil rata-rata ini disimpulkan bahwa nilai $\mathrm{IHD}_{\mathrm{V}}$ telah tereduksi setelah dipasangi Single Tuned Filter.

Pengujian Hipotesis Statistik Uji T berpasangan untuk variabel Faktor daya sebelum dipasangi Single Tuned Filter dan sesudah dipasangi Single Tuned Filter karena variabel Faktor Daya memiliki data yang terdistribusi normal baik sebelum ataupun sesudah dipasangi Single Tuned Filter. Hasil dari Pengujian Hipotesis Statistik ini adalah bahwa rata-rata Faktor Daya sebelum difilter $=0.8480$ dan rata-rata Faktor Daya setelah difilter $=0.9780$ dari rata-rata ini terlihat bahwa sesudah difilter rata-rata nilai faktor daya naik, berarti Single Tuned Filter ini mampu mereduksi frekuensi harmonik ke-3 dan menaikkan nilai faktor daya dengan baik.

\section{PERHITUNGAN RANGKAIAN SINGLE TUNED FILTER}

Berikut adalah rumus-rumus untuk melakukan perhitungan dalam perancangan Single Tuned Filter:

1. Perhitungan mencari nilai $Q_{V A R}$ 


$$
\begin{aligned}
& \quad Q_{V A R}=\sqrt{\left|\frac{0.255}{0.85}\right|^{2}+0.255^{2}}-\sqrt{\left|\frac{0.255}{0.9}\right|^{2}+0.255^{2}} \\
& =\sqrt{0.09-0.65}-\sqrt{0.080-0.65} \\
& =0.748-0.734 \\
& =0.00698 \mathrm{VAR}
\end{aligned}
$$

2. Perhitungan mencari nilai $X_{C}$

$$
X_{C}=\frac{220^{2}}{122.9}=\frac{48400}{122.9}=393.81 \Omega
$$

3. Perhitungan mencari nilai $\mathrm{C}$

$$
\mathrm{C}=\frac{1}{1 \times 3.14 \times 50 \times 393.81}=\frac{1}{123.656}=8.086 \mu \mathrm{F} \sim 10 \mu \mathrm{F}
$$

4. Perhitungan mencari nilai $X_{L}$

$$
X_{L}=\frac{393.81}{2.9^{2}}=\frac{393.81}{8.41}=46.826 \Omega
$$

5. Perhitungan mencari nilai $\mathrm{L}$

$$
\mathrm{L}=\frac{46.826}{2 \times 3.14 \times 50}=\frac{46.826}{314}=113 \mathrm{mH}
$$

6. Perhitungan resonansi pada frekuensi harmonik ke-3 yaitu $150 \mathrm{~Hz}$

$$
\mathrm{f}=\frac{1}{2 \times 3.14 \sqrt{113 m H \times 10 \mu \mathrm{F}}}=\frac{1}{66.75 \times 10^{-4}}=149.81 \mathrm{~Hz} \sim 150 \mathrm{~Hz}
$$

\section{KESIMPULAN DAN SARAN}

\section{Kesimpulan}

Berdasarkan hasil pengujian keseluruhan, dapat diberikan beberapa kesimpulan dan saran yaitu :

Berdasarkan pengujian dan analisis terhadap pengaruh Single Tuned Filter terhadap frekuensi harmonik ketiga pada beban rumah tangga $2200 \mathrm{VA}$, maka dapat disimpulkan bahwa:

1. Penurunan frekuensi harmonik ke-3 pada nilai $I_{H} D_{I}$ dan $I H D_{V}$ memiliki pengaruh positif yang cukup kuat terhadap nilai faktor daya, yaitu jika nilai $\mathrm{IHD}_{\mathrm{I}}$ dan $\mathrm{IHD}_{\mathrm{V}}$ mengecil maka nilai faktor daya akan membesar.

2. Nilai $\mathrm{IHD}_{\mathrm{I}}$ dan nilai $\mathrm{IHD}_{\mathrm{V}}$ pada beban rumah tangga $2200 \mathrm{VA}$ yang sudah dipasangi Single Tuned Filter lebih kecil dari nilai $\mathrm{IHD}_{\mathrm{I}}$ dan nilai $\mathrm{IHD}_{\mathrm{V}}$ pada beban rumah tangga 2200 VA yang belum dipasangi Single Tuned Filter.

3. Nilai faktor daya pada beban rumah tangga 2200 VA yang sudah dipasangi Single Tuned Filter lebih besar dari nilai faktor daya pada beban rumah tangga 2200 VA yang belum dipasangi Single Tuned Filter.

4. Filter pasif yang digunakan dalam penelitian ini yaitu Single Tuned Filter mampu mereduksi Frekuensi harmonik ke-3 dan menaikkan nilai faktor daya

\section{Saran}

Saran pada penelitian ini adalah diharapkan pada penelitian lainnya dapat membahas pengaruh Single Tuned Filter pada beban rumah tangga yang memiliki daya yang berbeda dan pada frekuensi harmonik lainnya.

[1] Associated Power Technologies, Total Harmonic Distortion and Effects in Electrical Power Systems. APT, 2011.

[2] S.W. Blume, "Electric Power System Basics for The Nonelectrical Professional". Wiley-Interscience: America. (2007)

[3] Harmonics and IEEE 519. EnergyLogix Solutions Inc.

[4] IEEE Std. 519-1992 - Recommended Practices and Requirements for Harmonic Control in Electrical Power Systems

[5] I. Priyadi, "Studi Penggunaan Rangkaian Filter untuk Mengurangi Efek Harmonisa pada Lampu Hemat Energi", Universitas Bengkulu, Bengkulu, Indonesia

[6] Y.S. Cho and H. Cha, Single-tuned Passive Harmonic Filter Design Considering Variances of Tuning and Quality Factor. Journal of International Council on Electrical Engineering Vol. 1 No. 1, pp 7 -13,2011. 
[7] E. Sopyandi. "Perancangan Single Tuned Filter untuk Mereduksi Arus dengan Simulasi Program ETAP Powerstation 5.0.3", Teknik Elektro,Universitas Indonesia, Depok, Indonesia

[8] Abiddin. F. J," ANALISIS UNJUK KERJA HARMONIK DIINSTALASI LISTRIK INDUSTRI DAN UPAYA PENANGGULANGGANNYA",Jurusan Teknik Elektro, Sekolah Tinggi Teknologi Nasional, Yogyakarta,Indonesia.

[9] Widiarto. E dan Jamaah.A,"Perancangan Low Pass RC Filter untuk Mereduksi Harmonik pada Lampu Hemat Energi (LHE) 20W”, Jurusan Teknik Elektro, Politeknik Negri Semarang, Semarang, Indonesia. 